\title{
KOMPARATIVNA ANALIZA RAZLIČITIH PRISTUPA KORIGIRANJU GEOMETRIJSKIH DISTORZIJA STARE ŠUMARSKE KARTE
}

\author{
COMPARATIVE ANALYSIS OF DIFFERENT APPROACHES TO \\ THE CORRECTION OF GEOMETRIC DISTORTION IN THE OLD \\ FORESTRY MAP
}

Nedim TUNO ${ }^{1 *}$, Admir MULAHUSIĆ* ${ }^{*}$ Jusuf TOPOLJAK ${ }^{1}$

\begin{abstract}
Sažetak
Geometrijske distorzije povijesnih šumarskih karata predstavljaju glavnu smetnju u postupcima integracije tih karata i drugih geoprostornih podataka. Efekti praktične primjene različitih postupaka uklanjanja deformacija karte detaljno su sagledani na ispitivanom listu stare šumarske karte Bosne i Hercegovine. Analizom različitih transformacijskih postupaka pokazano je da se najbolji rezultati ukupne točnosti transformacije karte ostvaruju uporabom kompleksnih polinomnih i lokalno osjetljivih modela, s obzirom na njihove sposobnosti uklanjanja neuniformnih i neravnomjerno raspoređenih distorzija sadržaja karte. Transformacijski model se znatno poboljšava ako se u njegovu osnovu uključe sve točke koordinatne mreže karte.
\end{abstract}

KLJUČNE RIJEČl: stara šumarska karta, geometrijske distorzije, istovjetne točke, transformacije koordinata

\section{UVOD}

\section{INTRODUCTION}

Vegetacija bitno određuje izgled i posebno vrijednost prirodne osnove nekog kraja, te se stoljećima velika pozornost poklanjala njezinom predstavljanju na različitim kartografskim prikazima (Lovrić 1988). Kartografi su oduvijek poseban naglasak stavljali na šume i šumska zemljišta, pa danas stare karte i planovi pružaju vrijedne informacije o strukturi šumskog pokrova u prošlosti. Šumarski planovi i karte predstavljaju vjerodostojne povijesne izvore koji svjedoče o povijesti gospodarenja šumama, te su neizostavan izvor u istraživanju razvoja organiziranog šumarstva (Pernar 2016). Stoga ne čudi što brojni autori upotrebljavaju upravo povijesne kartografske dokumente za retrospektivna istraživanja strukture vegetacijskog pokrova i njegovih mijena u različitim razdobljima (npr. Andraž i sur. 1998, Hamre i sur. 2007, Stanga i Niacsu 2016, itd.). Stari planovi i karte s prikazom informacija o površinama i prostornom rasporedu pokrova zemljišta sve se više analiziraju geografskim informacijskim sustavima (GIS) (Yang i sur. 2014). Usporedba povijesnih kartografskih materijala i suvremenih prostornih podataka zorno ocrtava promjene šuma i šumskog zemljišta na razmatranim područjima. Kako bi se podaci starih kartografskih prikaza mogli ispravno analizirati i koristiti u sprezi s prostornim podacima iz drugih izvora, nužno ih je georeferencirati. Svrha georeferenciranja uspostavljanje je veze između koordinatnog sustava digitalne slike i referentnoga koordinatnog sustava, uz uklanjanje de-

* doc. dr. sc. Nedim Tuno, izv. prof. dr. sc. Admir Mulahusić, doc. dr. sc. Jusuf Topoljak, Univerzitet u Sarajevu, Građevinski fakultet, Odsjek za geodeziju i geoinformatiku, Stjepana Tomića 1/III, 71000 Sarajevo, BiH, e-mail: nedim_tu@yahoo.com, nedim_tuno@gf.unsa.ba, admir_mulahusic@gf.unsa.ba, jusuf.topoljak@gf.unsa.ba. 
formacija slike geometrijskom transformacijom (Tuno i sur. 2011). U brojnim dosadašnjim istraživanjima na ovu temu, autori kao što su Jenny i Hurni (2011), Brovelli i Minghini (2012), Čada i Janečka (2017) i drugi, različitim postupcima transformacije eliminirali su odstupanja proizašla iz deformacija papira, nepravilnosti skeniranja i heterogenosti sadržaja povijesnih kartografskih dokumenata.

Prve geografske karte s prikazima šuma na prostoru Bosne i Hercegovine javljaju se početkom 16. stoljeća (Gašparović 1970), ali tek krajem 19. stoljeća nastaju planovi i karte koji donose prvu realnu kartografsku sliku granica šuma i šumskog zemljišta na cjelokupnoj teritoriji Bosne i Hercegovine. Kapitalno djelo austrijskih kartografa iz tog razdoblja bila je Šumarska karta Bosne i Hercegovine u mjerilu 1:50 000. O toj se karti još uvijek nedovoljno zna i vrlo se malo do sada o njoj pisalo. Kratke osvrte na njezin nastanak i glavne značajke dali su Gašparović (1970) i Marković (1998). Opis jednog lista karte prema Međunarodnom standardnom bibliografskom opisu kartografske građe - ISBD (CM), uz koji je prikazan i isječak, može se pronaći u (Mulahusić 2007), a isječak i opis drugog lista dali su Tuno i sur. (2011). Ovim su se radom nastojale upotpuniti spoznaje o izradi i karakteristikama te karte, a prvi put obavljena je detaljna analiza njezine matematičke osnove i kompleksnih geometrijskih distorzija, te istraženi različiti pristupi uklanjanju deformacija sadržaja karte.

\section{MATERIJALI I METODE}

\section{MATERIALS AND METHODS}

\section{Šumarska karta Bosne i Hercegovine - Forestry map of Bosnia and Herzegovina}

Nastanak prve tematske karte s točnim, detaljnim i sveobuhvatnim prikazom šumskih površina u Bosni i Hercegovini veže se za okupaciju te zemlje od strane Austro-Ugarske Monarhije, 1878. godine. Ubrzo nakon okupacije izdao je austrijski glavni stožer zapovijed Vojnogeografskom institutu (VGI) u Beču (njem. Wien: k.u.k. Militärgeographischen Institute - MGI) za izvođenje geodetske izmjere čitavog teritorija $\mathrm{BiH}$ u što kraćem vremenu (Marković 1998). Veliko šumsko bogatstvo $\mathrm{BiH}$, uz rudnog, najviše je privlačilo pozornost austrijskih okupacijskih vlasti, što početkom 1880 . godine rezultira odlukom o izradi pregledne karte šumskih kompleksa u mjerilu 1:50 000 (Gašparović 1970). Karta s vjerno ucrtanim granicama svih šuma i šumskog zemljišta, kao i drugim bitnim topografskim obilježjima prostora, trebala je doprinijeti kvalitetnom državnom gospodarenju šumskim područjima. S izradom šumarske karte započelo se odmah po završetku geodetske izmjere, preuzimanjem sadržaja dovršenih listova (sekcija) detaljne izmjere terena u mjerilu 1:12 500. Navedene sekcije su četverostrukim smanjivanjem dovođene u mjerilo 1:50 000, čime su dobivani sastavljački izvornici za montiranje u okvire listova buduće karte. Daljom kartografskom obradom (generaliziranjem) dolazilo se do izdavačkih izvornika, koji su fotolitografijom reproducirani samo u crnoj boji (Dimitz 1905). Naposljetku, Bečki VGI 1885. godine objavljuje velebno kartografsko djelo naslovljeno kao Šumarska karta Bosne i Hercegovine (njem. Forstkarte von Bosnien und der Hercegovina). Ona je tiskana u maloj nakladi od svega 200 kompleta, a svaki komplet sačinjavala su 223 lista karte. Ova je karta bila vlasništvo Ministarstva financija. Komplet Šumarskih karata Bosne i Hercegovine (u daljem tekstu koristit će se skraćenica ŠKBiH) danas je velika rijetkost, pa ga ne posjeduje ni Ratni arhiv u Beču (Marković 1998).

Kartografika primijenjena na ŠKBiH određena je prema ključu za crtanje simbola, odnosno zbirci znakova (njem. Zeichenmuster), tiskanoj u okviru upute za katastarsku izmjeru Bosne i Hercegovine (njem. Instruction für die Katastral-Vermessung Bosnien und Herzegovina). Tematska cjelina šumskog pokrova je na karti istaknuta popunjavanjem obrisa šumskih kompleksa površinskom signaturom u formi linijskog rastera vidljive strukture. Optičkim miješanjem crne boje rastera i bijele boje papira stvoren je dojam ispunjenosti šumskih cjelina sivom bojom, čime je dobro istaknut odnos pokrivenosti i nepokrivenosti zemljišta šumom. Posebnim kartografskim znakovima unutar kontura šuma ukazano je na vrstu drveća. Karta sadržava i prikaz položaja i nekih svojstava općegeografskih objekata (prometnice, hidrografija, naseljena mjesta, granične linije i sl.), koji je odabran tako da podupire i popunjava u njega uklopljeni tematski sadržaj.

Istraživanje provedeno u ovome radu podrazumijevalo je obradu jednog lista ŠKBiH, nomenklature XI/15 (slika 1), a koji se čuva u Arhivu Bosne i Hercegovine. U vezi s tim je bilo neophodno spomenuti list karte prevesti u digitalni rasterski oblik rotacijskim skenerom velikog formata, što je rezultiralo slikovnom datotekom u TIFF formatu (engl. Tagged Image File Format).

\section{Geometrijsko ispravljanje skenirane karte - Geometric correction of the scanned map}

Razmatrajući geometrijsku kvalitetu spomenutog lista ŠKBiH u rasterskom slikovnom formatu, može se realno pretpostaviti da je on opterećen neuniformnim i neravnomjerno raspoređenim geometrijskim distorzijama. Skenirani list karte sadržavat će sve pogreške koje su prisutne na analognom izvorniku, kao i pogreške skeniranja. Stoga je neophodno rastersku kartu geometrijski korigirati i dovesti na njezinu poziciju u ciljnom koordinatnom sustavu (Jenny i Hurni 2011). Pri izboru adekvatnog postupka geometrijske obrade skenirane karte treba znati kako je nastao kartografski izvornik i do kakvih je sve pogrešaka pritom moglo doći. Distorzije analogne karte uzrokovane su pogreškama primarnih podataka terenske geodetske izmjere, pogreškama izrade karte i deformacijama crtaće podloge zbog utjecaja temperature, vlage i starenja (Onur- 


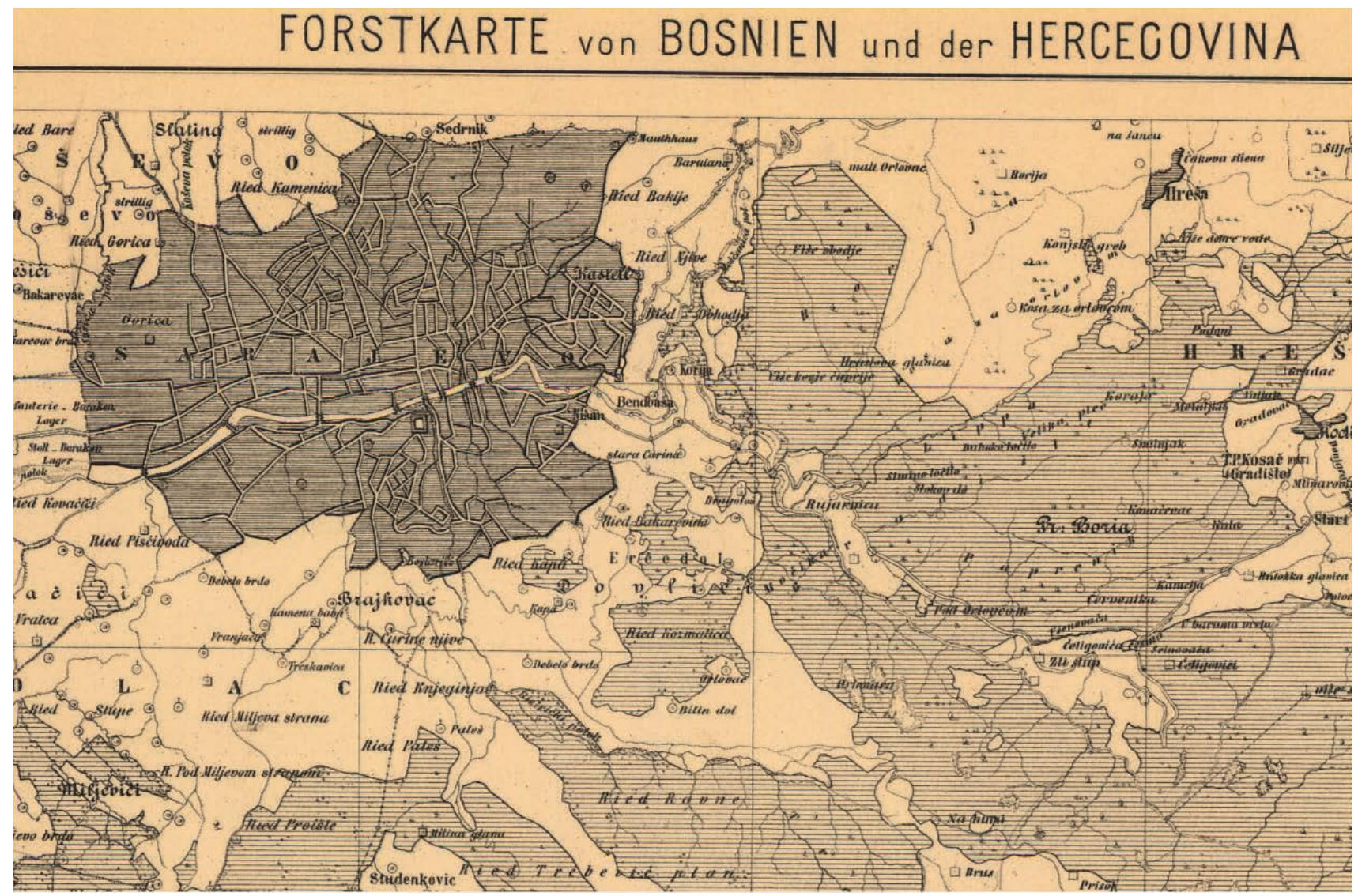

Slika 1. Isječak lista XI/15 Šumarske karte Bosne i Hercegovine (ŠKBiH) iz 1885. godine.

Figure 1 Clip of the Forest map of Bosnia and Herzegovina (FMBCH) Sheet XI/15 from 1885.

sal i Kizilsu 2000). U cilju korigiranja deformacija rasterske karte, nužno je repozicionirati piksele s njihovih izvornih lokacija u zadanu referentnu mrežu, pri čemu treba odabrati odgovarajući matematički model za uklanjanje distorzija i provesti transformaciju koordinata. $\mathrm{U}$ tom smislu se na temelju istovjetnih točaka određuje zakon preslikavanja i na osnovi njega transformiraju sve točke lista karte (Zhu 2016). Istraživanje geometrijskog korigiranja ŠKBiH podrazumijevalo je uporabu globalnih funkcijskih modela Helmertove, afine, projektivne i polinomne transformacije. Ispitane su i lokalno osjetliive transformacijske funkcije: multikvadratna (engl. multiquadratic - MQ), tankoslojni splajn (engl. thin-plate spline - TPS) i metoda lokalne težinske sredine (engl. local weighted mean - LWM). Detaljni opisi tih transformacija mogu se pronaći u literaturi vezanoj za geometrijsko ispravljanje rasterskih digitalnih slika (npr. Goshtasby 2005, Richards i Yia 2006 itd.).

\section{Definiranje istovjetnih točaka - Identical points definition}

Korespondentne točke putem kojih se ostvaruje veza izvornog koordinatnog sustava skenirane karte i ciljnog sustava, odnosno temeljem kojih se utvrđuju i otklanjaju deformacije karte, nazivaju se veznim ili istovjetnim (engl. tie points, identical points). Kao istovjetne točke obično se upotrebljavaju točke definirane presjecima linija koordinatne mreže ucrtane unutar okvira karte, jer su za njih poznate koordinate u izvornom i ciljnom sustavu. Točke koordinatne mreže su vrlo pogodne za ocjenu deformacija lista karte, zato što ravnomjerno prekrivaju cijeli list (Miladinović 2005).

Kako bi se točke koordinatne mreže mogle ispravno koristiti u procesu obrade ŠKBiH, nužno je poznavati geodetsku i matematičku osnovu te karte, a koja je istovjetna geodetskoj i matematičkoj osnovi izmjere. Geodetsku osnovu detaljne terenske izmjere činile su točke triangulacije svih redova, čije su ravninske koordinate izračunate u Cassini-Soldnerovoj poprečnoj cilindričnoj kartografskoj projekciji, prema elementima Besselovog elipsoida iz 1841. godine (Mugnier 2013). Ovako određene koordinate odnose se na horizontalni datum Bečkog sveučilišnog opservatorija i date su u zasebnim koordinatnim sustavima tzv. stupanjskih listova (tj. listova topografske „specijalne“ karte mjerila 1:75 000), kojih je za teritoriju BiH bilo ukupno 65. Njima su Zemljini sferoidni trapezi obrazovani mrežom meridijana i paralela na konstantnim rastojanjima $\Delta \lambda=30^{\prime}$ i $\Delta \varphi=15^{\prime}$ projicirani u ravninu kao jednakokračni ravni trapezi (poliedarska projekcija), čime je definiran koordinatni sustav bosanskog katastra (Glusic 1959). 


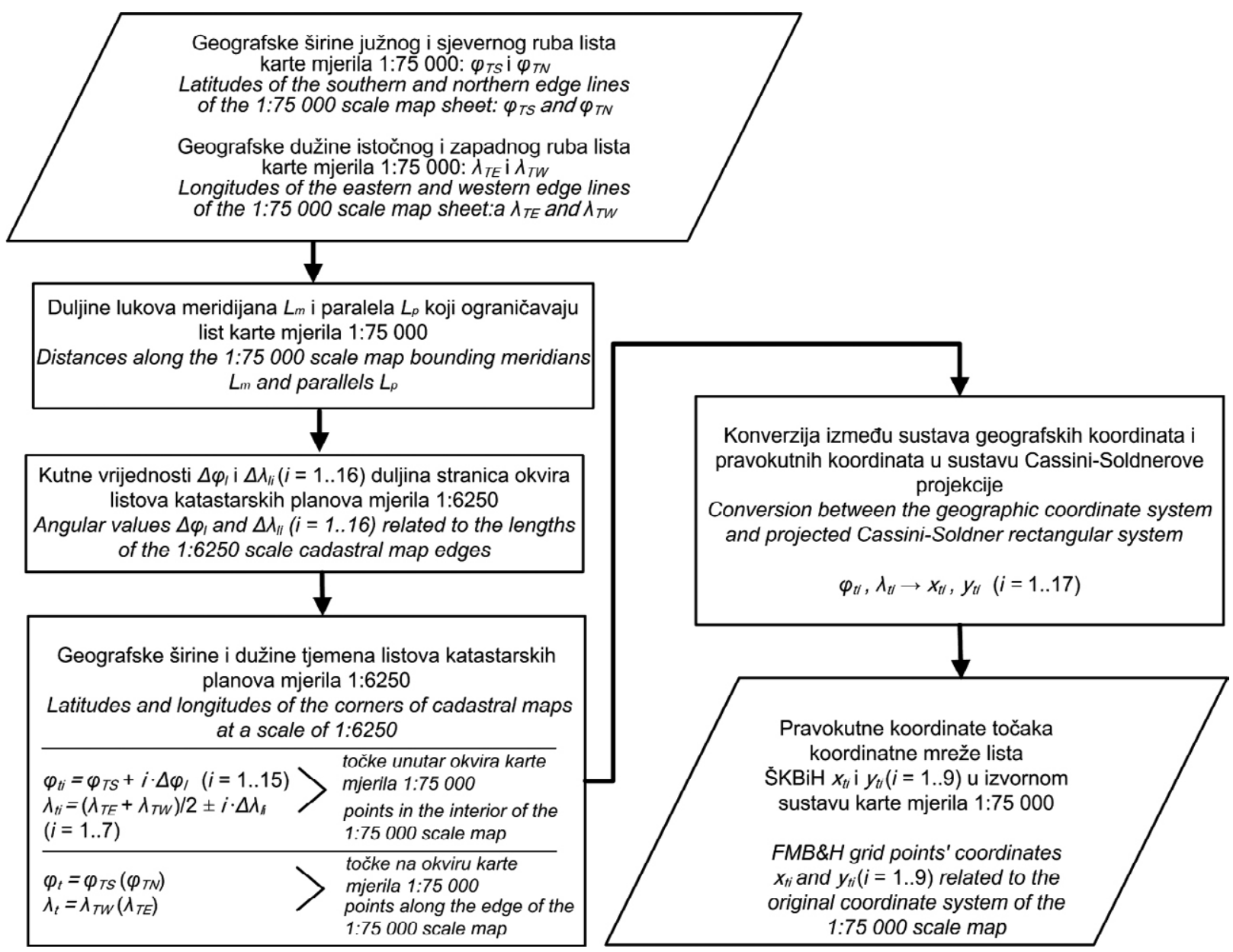

Slika 2. Dijagram procesa određivanja pravokutnih koordinata točaka koordinatne mreže listova ŠKBiH.

Figure 2 Activity flow diagram for determination of rectangular coordinates for the FMBGH coordinate grid ticks.

Podjela na listove ŠKBiH obavljena je u navedenom sustavu dijeljenjem svakog stupanjskog lista na četiri lista ŠKBiH. Stoga okvir lista ŠKBiH ima oblik pravokutnog trapeza, čije su stranice dijelovi meridijana i paralela izvučeni pravim linijama. Dimenzije listova iznose 7’30“' (približno $14 \mathrm{~km}$ ) po geografskoj širini i 15' (približno $20 \mathrm{~km}$ ) po geografskoj dužini. Tjemena lista obilježena su na karti njihovim geografskim koordinatama. Unutar lista dana je pravokutna koordinatna mreža, čije su linije paralelne osima $x$ i $y$ koordinatnog sustava stupanjskog lista. Za razliku od suvremenijih karata, kod kojih je na izvan okvirnome prostoru lista svaka linija koordinatne mreže označena odgovarajućim brojem kilometara ili metara u odnosu na referentnu os usvojenog koordinatnog sustava, to kod ŠKBiH nije slučaj. Stoga je neophodno izračunati koordinate točaka koordinatne mreže u izvornome sustavu stupanjskog lista. Linijama koordinatne mreže zapravo je list ŠKBiH podijeljen na listove katastarskih planova mjerila 1:6250 (56 listova pravokutnog oblika i 8 listova trapeznog oblika), te se navedeni problem svodi na prostorno referenciranje tjemena katastarskih planova. Podjela na listove katastarskih planova u sustavu bosanskog katastra objašnjena je u uputama za katastarsku izmjeru $\mathrm{BiH}$. Za potrebe ovog istraživanja osmi- šljen je praktični postupak računanja koordinata presjeka linija koordinatne mreže ŠKBiH (slika 2) i implementiran u vlastitom softverskom rješenju, napisanom u programskom jeziku Visual Basic for Application (VBA). Na temelju unesenih geografskih koordinata tjemena stupanjskog lista, automatski se dobiju pravokutne Cassini-Soldnerove koordinate 81 točke na okviru i u polju lista $̌ K \mathrm{KBiH}$, a kojima je definirana njezina koordinatna mreža (slika 3).

\section{Ocjena planimetrijske točnosti karte - Assessment of the horizontal map accuracy}

Kvaliteta prostornih informacija prikazanih na geometrijski ispravljenoj rasterskoj slici ŠKBiH u izravnoj je vezi s primijenjenim postupkom georeferenciranja skenirane karte. Stoga je neophodno za sve provedene varijante georeferenciranja ocijeniti 2D (horizontalnu, tj. planimetrijsku) točnost transformirane karte, kako bi se ispitalo u kojoj su mjeri provedenim transformacijama otklonjene sustavne pogreške koje proizlaze iz deformacija nosioca karte, nepravilnosti skeniranja i izrade izvorne analogne karte. Za analizu $2 \mathrm{D}$ točnosti u ovome radu primijenjena je izravna metoda, opisana normom ISO 19157 Geographic information - Data quality (Geografske informacije - kvaliteta po- 


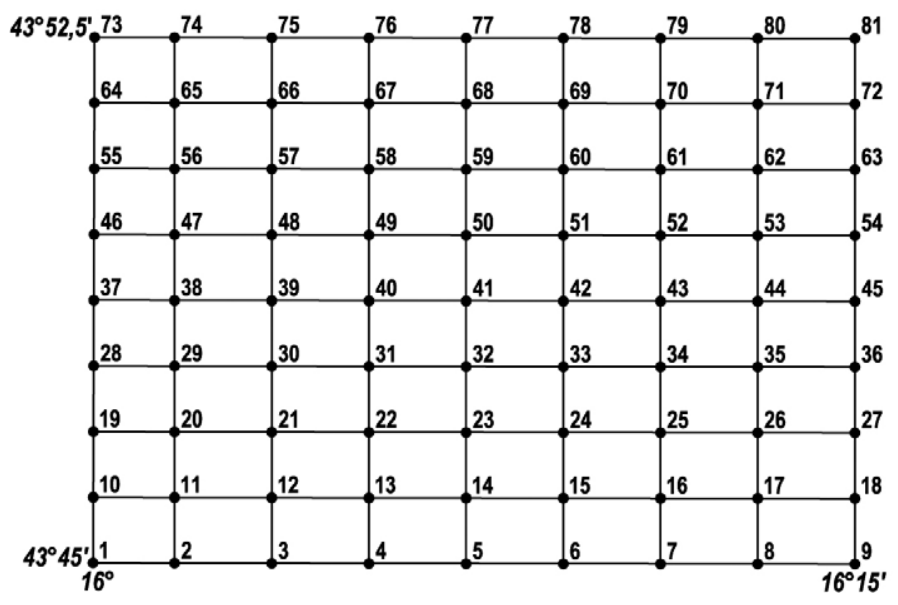

Slika 3. Koordinatna mreža lista $\mathrm{XI} / 15$ ŠKBiH.

Figure 3 Map grid of the FMBGH Sheet XI/15.

dataka), kojom se kvaliteta ocjenjuje usporedbom s odgovarajućim referentnim informacijama. Glede toga bilo je neophodno definirati kontrolne (testne) točke (engl. check points), koje su predočene na ŠKBiH, a čije su koordinate u ciljnom koordinatnom sustavu određene većom točnošću u odnosu na podatke koji se testiraju. Kako je ranije istaknuto, izvornici za izradu ŠKBiH bili su listovi karte mjerila 1:12 500. Na tim su listovima tijekom geodetske izmjere grafičkim putem izravno određivane $2 \mathrm{D}$ koordinate točaka triangulacije nižih redova i ostalih točaka neophodnih za izmjeru detalja geodetskim stolom. S obzirom na to da su iste točke prikazane na ŠKBiH sa znatno lošijom položajnom kvalitetom u odnosu na kartu 1:12 500 (zbog četiri puta sitnijeg mjerila i pogrešaka pri sastavljanju karte), ispunjen je kriterij neophodne točnosti za referentne podatke, odnosno te su se točke mogle koristiti kao kontrolne. Kako se spomenutom ISO normom definiraju samo opći principi i procedure, ovdje se primijenila Američka norma za točnost prostornih podataka (engl. National Standard for Spatial Data Accuracy, skraćeno NSSDA). NSSDA za ocjenu horizontalne točnosti koristi korijen srednje kvadratne po-

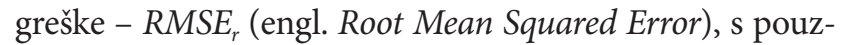
danošću $68,3 \%$, te horizontalnu točnost s pouzdanošću $95 \%$ koja se označava kao Accuracy ${ }_{r}$. Detaljan opis mjera točnosti te norme, statistika koje se koriste prigodom izvještavanja o kvalitetu i metodologiji dobivanja ocjene dan je u (FDGC 1998).

\section{REZULTATI I RASPRAVA}

\section{RESULTS AND DISCUSSION}

Ispitivanje utjecaja gustoće istovjetnih točaka na kvalitetu geometrijske obrade karte - Examining the influence of the density of identical points on the quality of geometric map processing

Točnost geometrijskih transformacija umnogome ovisi o broju i rasporedu (gustoći) istovjetnih točaka (Cetl i sur. 2010). Kako bi se ispitalo na koji način gustoća istovjetnih točaka (IT) utječe na horizontalnu točnost transformacije ŠKBiH, odabrano je 5 različitih gustoća istovjetnih točaka, pri čemu se vodilo računa o njihovom pravilnom rasporedu. Za razliku od broja kontrolnih točaka koji je stalan (ukupno 331 točka), istovjetne točke su se mijenjale po broju i rasporedu ovako (pozicije točaka predočene su na slici 3):

-1. varijanta: 4 IT (1 IT / $69.8 \mathrm{~km}^{2}$ ) - točke 1, 9, 73 i 81,

- 2. varijanta: 9 IT (1 IT / $31.0 \mathrm{~km}^{2}$ ) - točke 1, 5, 9, 37, 41, $45,73,77$ i 81 ,

- 3. varijanta: 15 IT (1 IT / $\left.18.6 \mathrm{~km}^{2}\right)$ - točke 1, 3, 5, 7, 9, 37, $39,41,43,45,73,75,77,79$ i 81 ,

- 4. varijanta: 25 IT (1 IT / $\left.11.2 \mathrm{~km}^{2}\right)$ - točke $1,3,5,7,9,19$, $21,23,25,27,37,39,41,43,45,55,57,59,61,63,73,75$, 77,79 i 81 ,

- 5. varijanta: 81 IT (1 IT / $3.4 \mathrm{~km}^{2}$ ) - sve raspoložive točke.

Izloženim načinom omogućena je usporedba rezultata transformacija provedenih s različitim gustoćama istovjetnih točaka. Pritom je kao funkcijski model transformacije korištena lokalno osjetljiva metoda tankoslojnog splajna (TPS).

Korištenjem koordinata kontrolnih točaka $(i=1,2, \ldots, 331)$ dobivenih s karte mjerila 1:12 $500\left(x_{i}, y_{i}\right)$ i transformiranih koordinata sa $\check{S} \mathrm{KBiH}\left(x_{i}^{t r}, y_{i}^{t r}\right)$, provedena je ocjena horizontalne točnosti TPS transformacija prema standardu NSSDA. Tablica 1 prikazuje kvalitetu transformirane $\check{S} \mathrm{KBiH}$, procijenjenu na temelju odstupanja koordinata kontrolnih točaka, transformirane ŠKBiH, procijenjenu na temelju odstupanja koordinata kontrolnih točaka, $d_{x_{i}}=x_{i}-x_{i}^{t r} \mathrm{i} d_{y_{i}}=y_{i}-y_{i}^{t r}$, te položajnih odstupanja $d_{x y_{i}}=\sqrt{d_{x_{i}}^{2}+d_{y_{i}}^{2}}$.

Analiza podataka iz tablice 1 pokazuje da su nakon 1. varijante transformacije (četiri IT definirane rubnim točkama okvira karte) prisutna velika apsolutna odstupanja i unutarnja nehomogenost podataka lista ŠKBiH. Vrijednosti iz tablice 1 jasno pokazuju kako se povećanje broja istovjetnih točaka povoljno odražava na smanjenje položajnih odstupanja, koja se javljaju pri transformaciji lista ŠKBiH. Najbolje rezultate dala je najveća gustoća IT, gdje $R M S E_{r}$ iznosi

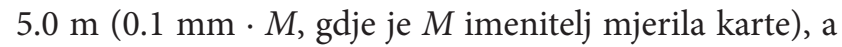


Tablica 1. Statistika preostalih geometrijskih distorzija ŠKBiH nakon TPS transformacije za različite varijante izbora veznih točaka Table 1. Statistics of remained geometric distortions in FMBGH after performing TPS transformation for the different variants of tie points selection

\begin{tabular}{|c|c|c|c|c|c|c|c|c|c|c|c|c|c|c|c|c|}
\hline \multirow{2}{*}{$\begin{array}{l}\text { Pokazatelj } \\
\text { Indicator } \\
d_{x}\end{array}$} & & \multicolumn{3}{|c|}{$\begin{array}{c}\text { Varijanta } 1 \\
\text { Variant } 1 \\
\end{array}$} & \multicolumn{3}{|c|}{$\begin{array}{c}\text { Varijanta } 2 \\
\text { Variant } 2 \\
\end{array}$} & \multicolumn{3}{|c|}{$\begin{array}{c}\text { Varijanta } 3 \\
\text { Variant } 3 \\
\end{array}$} & \multicolumn{3}{|c|}{$\begin{array}{c}\text { Varijanta } 4 \\
\text { Variant } 4 \\
\end{array}$} & \multicolumn{3}{|c|}{$\begin{array}{c}\text { Varijanta } 5 \\
\text { Variant } 5 \\
\end{array}$} \\
\hline & & $d_{x}$ & $d_{y}$ & $d_{x y}$ & $d_{x}$ & $d_{y}$ & $d_{x y}$ & $d_{x}$ & $d_{y}$ & $d_{x y}$ & $d_{x}$ & $d_{y}$ & $d_{x y}$ & $d_{x}$ & $\mathrm{~d}_{\mathrm{y}}$ & $d_{x y}$ \\
\hline \multicolumn{2}{|l|}{$\begin{array}{l}\text { Minimum [m] } \\
\text { Minimum }[\mathrm{m}]\end{array}$} & -17.1 & -13.9 & 0.8 & -9.2 & -15.1 & 0.4 & -7.9 & -8.8 & 0.1 & -10.5 & -11.1 & 0.6 & -5.3 & -10.4 & 0.2 \\
\hline \multicolumn{2}{|c|}{$\begin{array}{l}\text { Sredina }[\mathrm{m}] \\
\text { Average }[\mathrm{m}]\end{array}$} & -4.8 & 3.7 & 8.8 & 0.8 & 0.0 & 5.6 & -0.5 & 3.6 & 5.6 & -0.4 & -0.9 & 5.2 & 0.5 & -0.4 & 4.1 \\
\hline \multicolumn{2}{|c|}{$\begin{array}{l}\text { Maksimum [m] } \\
\text { Maximum [m] }\end{array}$} & 11.4 & 28.3 & 28.6 & 11.1 & 15.9 & 17.2 & 10.6 & 16.7 & 18.0 & 7.5 & 15.6 & 17.2 & 8.3 & 15.3 & 16.2 \\
\hline \multicolumn{2}{|l|}{$\begin{array}{l}\text { Raspon }[\mathrm{m}] \\
\text { Range }[\mathrm{m}]\end{array}$} & 28.5 & 42.2 & 27.8 & 20.2 & 31.0 & 16.7 & 18.5 & 25.6 & 17.9 & 18.0 & 26.7 & 16.6 & 13.6 & 25.7 & 16.0 \\
\hline \multicolumn{2}{|l|}{ RMSE [m] } & 6.0 & 7.7 & 9.8 & 4.5 & 4.9 & 6.6 & 3.3 & 5.6 & 6.5 & 3.9 & 4.5 & 6.0 & 2.5 & 4.3 & 5.0 \\
\hline \multirow{6}{*}{ 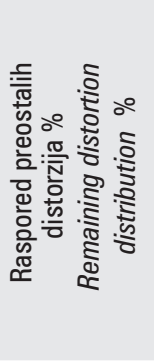 } & $0-5$ & 49.2 & 48.0 & 19.3 & 67.7 & 75.8 & 52.3 & 85.5 & 64.0 & 47.1 & 76.4 & 76.1 & 53.2 & 95.5 & 77.9 & 70.1 \\
\hline & $5-10$ & 44.1 & 35.6 & 48.6 & 30.8 & 18.1 & 34.7 & 14.2 & 29.0 & 44.1 & 23.3 & 19.6 & 39.0 & 4.5 & 18.4 & 26.3 \\
\hline & $10-15$ & 6.0 & 9.4 & 22.7 & 1.5 & 5.1 & 11.5 & 0.3 & 5.4 & 6.9 & 0.3 & 3.6 & 7.3 & 0.0 & 3.3 & 3.3 \\
\hline & $15-20$ & 0.6 & 6.0 & 7.9 & 0.0 & 0.9 & 1.5 & 0.0 & 1.5 & 1.8 & 0.0 & 0.6 & 0.6 & 0.0 & 0.3 & 0.3 \\
\hline & $20-25$ & 0.0 & 0.6 & 1.2 & 0.0 & 0.0 & 0.0 & 0.0 & 0.0 & 0.0 & 0.0 & 0.0 & 0.0 & 0.0 & 0.0 & 0.0 \\
\hline & $>25$ & 0.0 & 0.3 & 0.3 & 0.0 & 0.0 & 0.0 & 0.0 & 0.0 & 0.0 & 0.0 & 0.0 & 0.0 & 0.0 & 0.0 & 0.0 \\
\hline
\end{tabular}

Accuracy $_{r}$ je $8.3 \mathrm{~m}$. U toj varijanti transformacije, vrijednosti $R M S E_{r}$ i raspona položajnih odstupanja smanjeni su gotovo dva puta u odnosu na prvu varijantu, a čak $96.4 \%$ položajnih odstupanja ima manju vrijednost od $10 \mathrm{~m}(0.2 \mathrm{~mm}$ - M). Opadanje veličine $R M S E_{r}$ preostalih distorzija transformirane karte, kao i vrijednosti maksimalnih položajnih odstupanja, može se vrlo dobro modelirati funkcijom opće potencije (slika 4).

Osim opisane numeričke ocjene rezultata provedene su i vizualne kontrole, kojima su potvrđeni prethodni navodi. Primjer rezultata transformacije na uzorku od sveukupno
34 kontrolne točke izabranog područja dimenzija $2200 \mathrm{x}$ 2700 m, u jugozapadnom dijelu lista ŠKBiH, dat na slici 5. Preostale distorzije u transformiranim točkama prikazane su za 1. varijantu transformacije (slika 5a) i 5. varijantu (slika 5b). Vizualizacija planimetrijske točnosti vektorima pomaka otkriva da položajna odstupanja nakon transformacije temeljem samo četiri točke koordinatne mreže imaju isti smjer rasprostiranja sjeverozapad-jugoistok (globalna sistematičnost), a intenziteti im u prosjeku imaju velike vrijednosti $\left(R M S E_{r}=11.6 \mathrm{~m}\right)$. S druge strane, grafička prezentacija horizontalne točnosti transformacijskog modela za-

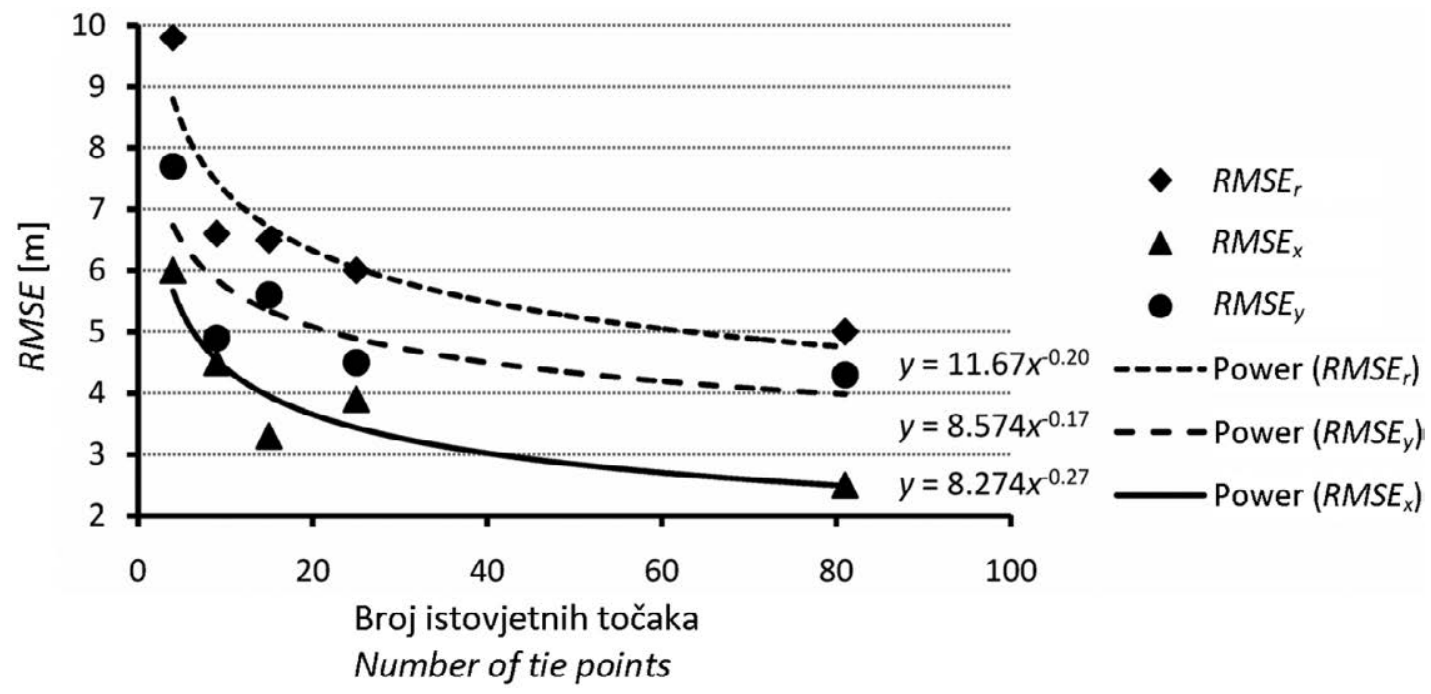

Slika 4. Trendovi promjena vrijednosti RMSE u ovisnosti o korištenom broju istovjetnih točaka.

Figure 4 Trends of RMSE value changes depending on the number of common points used. 


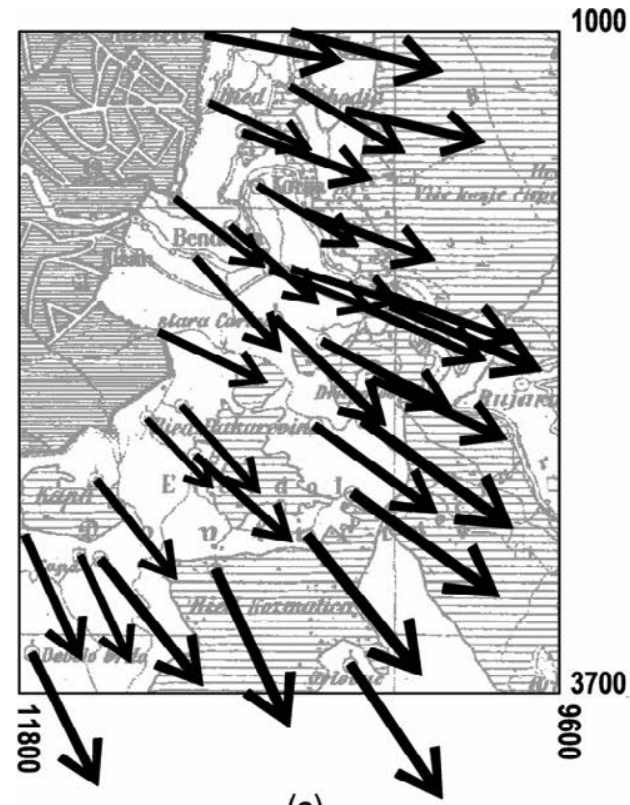

(a)

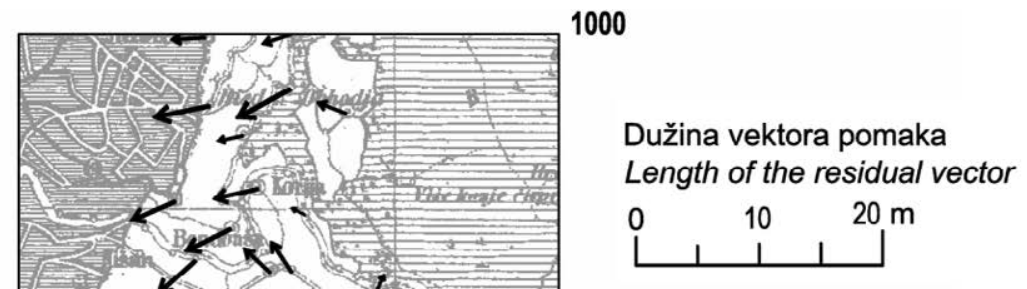

Dužina u stvarnosti Distance on the ground

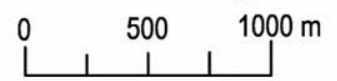

Dužina na karti Distance on the map

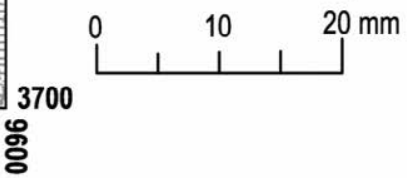

(b)

Slika 5. Efekti TPS transformacije temeljem 4 točke (a) i 81 točke koordinatne mreže (b)

Figure 5 Effects of TPS transformation performed with the use of 4 points (a) and 81 points in the map grid (b).

snovanog na svim točkama koordinatne mreže jasno ilustrira ostvareni trend poboljšanja transformiranih podataka. Ovdje su vektori pomaka znatno prigušeni $\left(R M S E_{r}=\right.$ $2.8 \mathrm{~m}$ ), a smjer rasprostiranja im je u najvećoj mjeri slučajnog karaktera.

\section{Analiza primijenjenog funkcijskog modela transformacije na kvalitetu geometrijske obrade karte - Analysis of the applied functional transformation model on the quality of geometric map processing}

S obzirom na to da primjena različitih transformacijskih funkcija daje različite vrijednosti koordinata korigirane rasterske slike (Goshtasby 2005), neophodno je provesti analizu točnosti različitih geometrijskih transformacija koje se mogu primijeniti pri ispravljanju skeniranog lista ŠKBiH. U tu je svrhu korištena 331 ranije definirana kontrolna točka, za sagledavanje stvarnih efekata primjene različitih modela transformacije oslonjenih na 81 točku koordinatne mreže.

Kako opseg članka ne dopušta detaljan prikaz svih dobivenih rezultata, na slici 6 su grafički prezentirani samo osnovni pokazatelji ocjene točnosti $\left(R M S E_{r}\right.$ i maksimalni $\left.d_{x y}\right)$. Najlošiji rezultate dala je Helmertova (slična) transformacija, jer se kod nje definira najmanji broj transformacijskih parametara - promjena mjerila, rotacija i translacije po koordinatnim osima. Provedenom analizama pokazane su i manjkavosti afine 6-parametarske i projektivne 8-parametarske transformacije u obuhvaćanju složenog rasporeda sustavnih efekata distorzije na ŠKBiH. Povećanjem stupnja polinoma kod polinomnih transformacija raste broj tran- sformacijskih parametara, što se pozitivno odražava na eliminiranje deformacija u pojedinim točkama karte. Najbolji rezultat u pogledu kvalitete rezultata transformacije ostvaren je uporabom polinoma 5. stupnja (40 transformacijskih parametara), gdje $R M S E_{r}$ iznosi $4.5 \mathrm{~m}$, a Accuracy ${ }_{r}$ je $7.5 \mathrm{~m}$. To govori kako ravnomjerni raspored i razmaci tjemena koordinatne mreže na ŠKBiH osiguravaju da se polinomnim transformacijama viših stupnjeva mogu učinkovito ukloniti distorzije, pri čemu se na prostoru između istovjetnih točaka neće javiti neželjena odstupanja. Navedeno potvrđuje i grafička prezentacija rasporeda preostalih distorzija na izabranom dijelu karte, nakon provedenih globalnih transformacija (slika 7). Vektori pomaka razlika koordinata 26 kontrolnih točaka transformiranih afinim modelom (slika 7a) jasno pokazuju da se nakon transformacije bitno ne mijenja raspodjela lokalnih sustavnih utjecaja u odnosu na situaciju prije same transformacije (vektori imaju ujednačenu orijentaciju i veliki intenzitet $-R M S E_{r}=$ $16.5 \mathrm{~m}$ ). Poslije transformacije polinomnim modelom 5. stupnja (slika 7b), na karti ostaju određena odstupanja koja zorno ilustriraju eliminiranje najvećeg dijela sustavnih utjecaja na razmatranom području $\left(R M S E_{r}\right.$ u tom slučaju iznosi $4.0 \mathrm{~m}$ ). Slika 8 pokazuje tendencije kretanja vrijednosti $R M S E_{r}$ i Accuracy, u ovisnosti o primijenjenom modelu polinomne transformacije, koje se mogu dobro modelirati polinomnom funkcijom drugog stupnja. Za nijansu lošiji rezultati geometrijske rektifikacije skenirane ŠKBiH, u odnosu na polinomne transformacije 5. i 6. stupnja, ostvareni su primjenom transformacijskih postupaka temeljenih na radijalnim baznim funkcijama (TPS i MQ), te LWM metodom. 


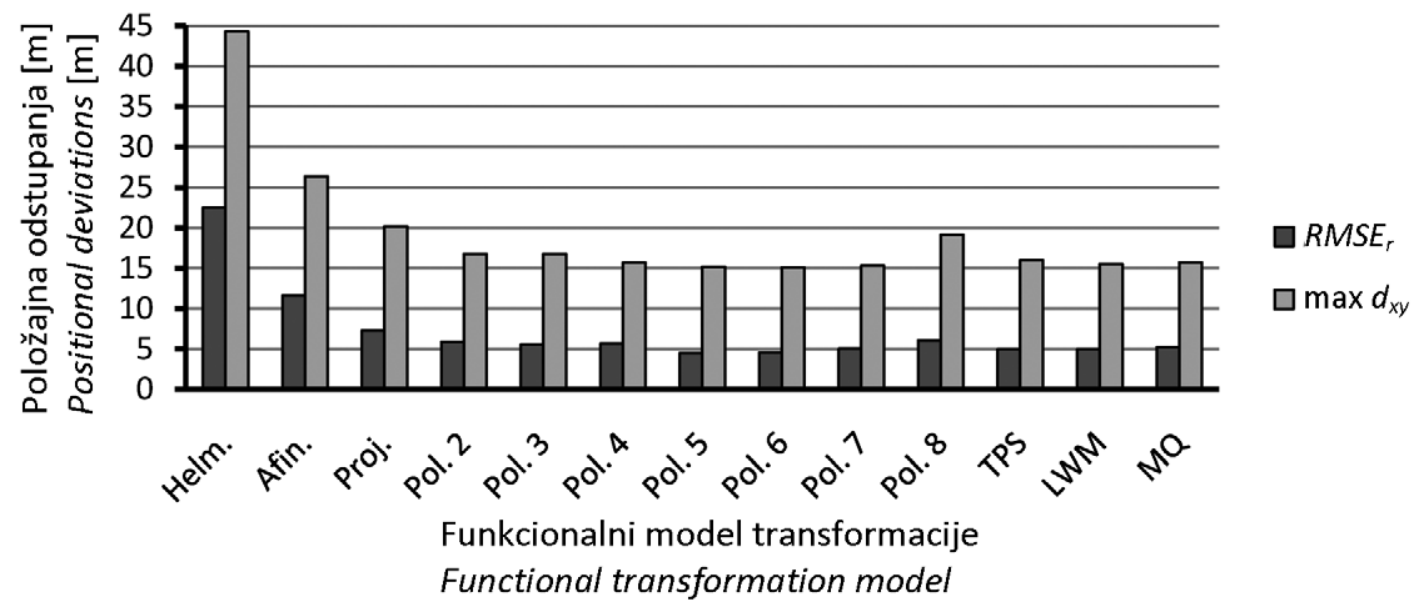

Slika 6. Vrijednosti RMSEr i maksimalnih položajnih odstupanja za različite transformacijske funkcije.

Figure 6 Values of RMSEr and maximum position deviations for different transformation functions.

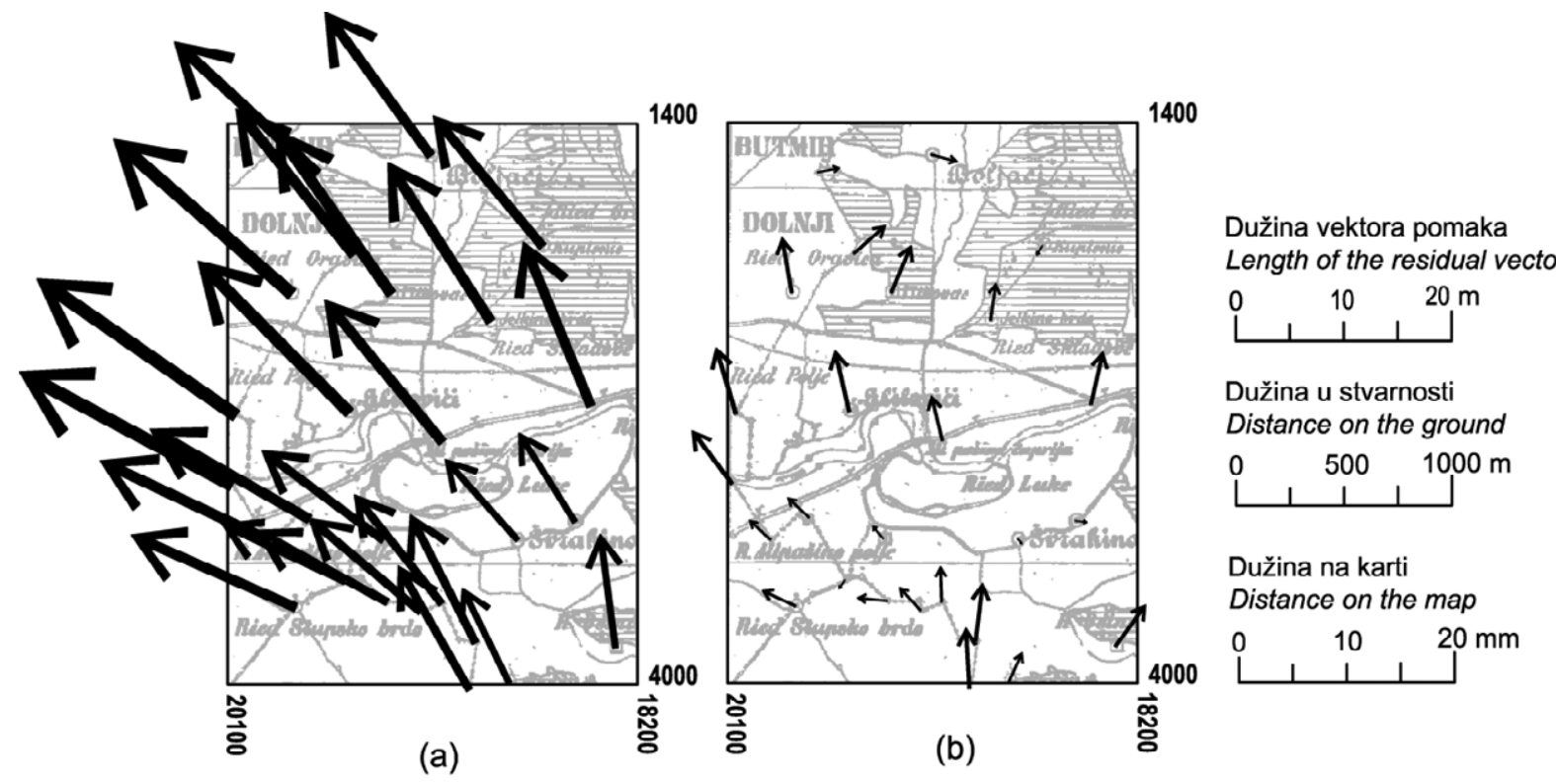

Slika 7. Preostale distorzije kontrolnih točaka nakon provedene afine transformacije (a) i polinomne transformacije 5. stupnja (b). Figure 7 Remaining distortions of control points after performing affine transformation (a) and 5th order polynomial transformation (b).

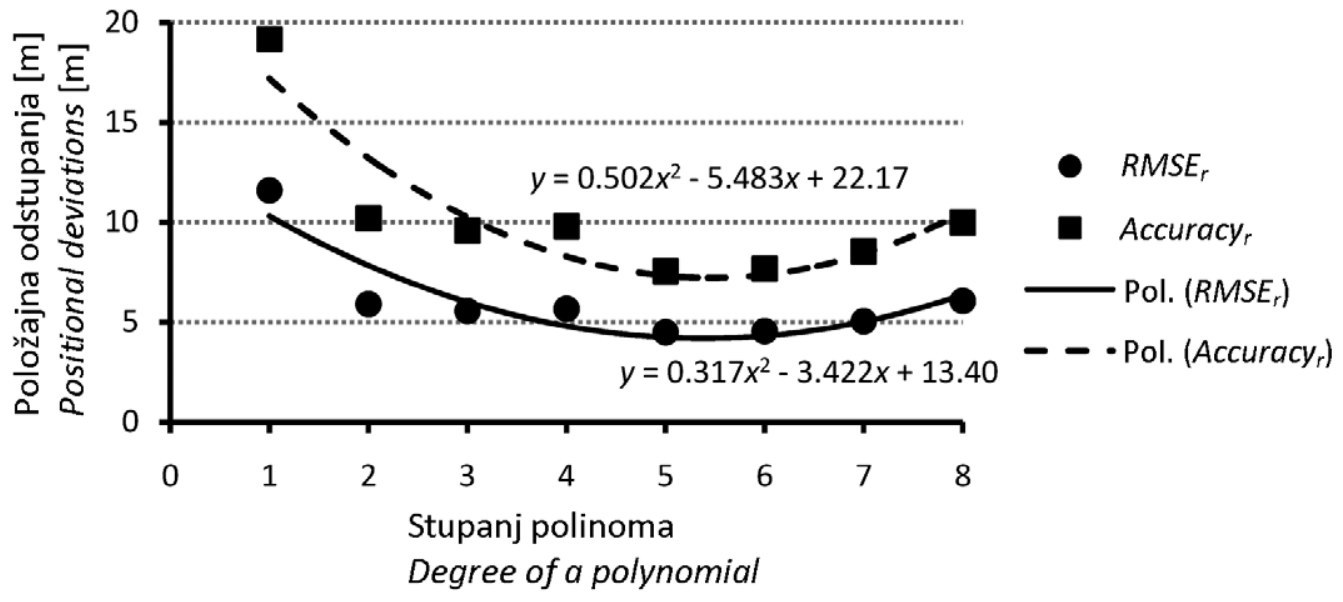

Slika 8. Trendovi promjena vrijednosti RMSEr i Accuracyr u ovisnosti o korištenom stupnju polinoma.

Figure 8 Trends of RMSEr and Accuracyr values changes depending on used polynomial degree. 


\section{ZAKLJUČCI}

\section{CONCLUSIONS}

Kvalitetna geometrijska obrada starih šumarskih karata zahtijeva dobro poznavanje teorije kartografskih projekcija, matematičke i geodetske osnove karte, sustava koordinata na elipsoidu i u ravnini, procesa izrade kartografskih izvornika, uzroka geometrijskih distorzija sadržaja skeniranih karata i transformacije koordinata u ravnini. Provedenim istraživanjem pokazana je uloga ispravnog izbora osnove transformacije (veznih točaka) i odgovarajućeg funkcionalnog transformacijskog modela u uspješnom otklanjanju sustavnih pogrešaka prouzročenih deformacijama crtaćeg materijala, nepravilnostima skeniranja i pogreškama prvobitne izrade i reprodukcije analogne karte. Dobiveni pokazatelji ocjene planimetrijske točnosti transformirane karte jasno pokazuju veoma loše rezultate postupka georeferenciranja koji se često koristi u praksi, a koji podrazumijeva dovođenje lista karte u teorijske dimenzije i pozicioniranje u izabrani koordinatni sustav upotrebom samo četiri rubne točke okvira karte. Pristup koji rezultira izrazito homogenim podacima transformirane karte temelji se na uključenju svih točaka koordinatne mreže u transformacijski model. Rezultati provedenih analiza daju upečatljivu sliku eliminiranja heterogenosti sadržaja karte uporabom odgovarajućih funkcijskih modela transformacije. Sveprisutne kartografske deformacije ne mogu se značajnije popraviti globalnim transformacijama temeljenim na malom broju parametara. Kompleksne geometrijske distorzije lista karte uspješno se obuhvaćaju i u najvećoj mjeri uklanjaju tek primjenom složenih polinomnih transformacija i lokalno osjetliivih transformacija. Ispravnim pristupom geometrijskoj obradi lista ŠKBIH starog više od 130 godina, tiskanog na običnom kartografskom papiru i čuvanog u neadekvatnim uvjetima, postignuto je da preostala odstupanja transformiranih točaka imaju slučajni karakter, odnosno ostvarena je vrlo visoka unutarnja položajna točnost korigirane karte. Provedenom geometrijskom obradom karta je pozicionirana u odnosu na horizontalni datum Bečkog sveučilišnog opservatorija, te bi nastavak istraživanja trebalo usmjeriti ka iznalaženju najpogodnijeg načina njezine transformacije u današnji službeni koordinatni sustav $\mathrm{BiH}$.

\section{LITERATURA}

\section{REFERENCES}

- Brovelli, M. A., M. Minghini, 2012: Georeferencing old maps: a polynomial-based approach for Como historical cadastres, ePerimetron, 7 (3): 97-110.

- Cetl, V., B. Barišić, I. Šarušić, 2010: Prevođenje katastarskih podataka u novi državni koordinatni sustav HTRS96/TM, Šumarski list, CXXXIV (11-12): 593-602.

- Čada, J., K. Janečka, 2017: Localization of Manuscript Müller's Maps, The Cartographic Journal, 54 (2): 126-138.
- Čarni, A., M. Jarnjak, K. Oštir-Sedej, 1998: Past and present forest vegetation in NE Slovenia derived from old maps, Applied Vegetation Science, 1 (2): 253-258.

- Dimitz, L., 1905: Die Forstlichen Verhältnisse und Einrichtungen Bosniens und der Hercegovina, Wilhelm Frick, k. u. k. Hofbuchhandlung, 390 p., Vienna.

- FGDC (Federal Geographic Data Committee), 1998: Geospatial Positioning Accuracy Standards, Part 3: National Standard for Spatial Data Accuracy (NSSDA), FGDC-STD-007.3, 28 p., Washington.

- Gašparović, R., 1970: Bosna i Hercegovina na geografskim kartama od prvih početaka do kraja XIX vijeka, Akademija nauka i umjetnosti Bosne i Hercegovine, 339 str., Sarajevo.

- Glusic, A. M., 1959: Mapping of the Countries in Danubian and Adriatic Basin, Corps of Engineers, U.S. Army, Army Map Service, 406 p., Washington.

- Goshtasby, A. A., 2005: 2-D and 3-D Image Registration for Medical, Remote Sensing, and Industrial Applications, John Wiley \& Sons, Inc., 284 p., Hoboken, New Jersey.

- Hamre, L. N., S. T. Domaas, I. Austad, K. Rydgren, 2007: Landcover and structural changes in a western Norwegian cultural landscape since 1865, based on an old cadastral map and a field survey, Landscape Ecology, 22 (10): 1563-1574.

- Jenny, B., L. Hurni, 2011: Studying cartographic heritage: Analysis and visualization of geometric distortions, Computers \&Graphics, 35 (2011): 402-411.

- Lovrić, P., 1988: Opća kartografija, Sveučilišna naklada Liber, 291 str., Zagreb.

- Marković, M., 1998: Descriptio Bosnae \& Hercegovinae : Bosna i Hercegovina na starim zemljovidima, AGM, 485 p., Zagreb.

- Miladinović, M., 2005: Geodetski planovi, http://www.scribd. com/doc/203228058/ 91Geodetski-Planovi-MM\#scribd (posjećeno: prosinca 2016).

- Mugnier, C., 2013: Grids \& Datums - Boznia and Herzegovina, Photogrammetric Engineering \& Remote Sensing, 79 (3): 229230.

- Mulahusić, A., 2007: Kartografija Sarajeva, Građevinski fakultet Univerziteta u Sarajevu, 228 str., Sarajevo.

- Onursal, G., Z. Kizilsu, 2000: Determining Angular and Linear Distortions on the Map Base, Journal of Surveying Engineering, 126 (4): 123-144.

- Pernar, R., 2016: Šumarske karte i planovi - iz povijesti gospodarenja šumama Hrvatske, Šumarski list, CXXXX (1-2): 100103.

- Richards, J. A., Jia, X., 2006: Remote sensing digital image analysis : an introduction, Springer-Verlag, 439 p., Berlin Heidelberg.

- Stanga, I. C., L. Niacsu, 2016: Using old maps and soil properties to reconstruct the forest spatial pattern in the late 18th century, Environmental Engineering \& Management Journal, 15 (6): 1369-1378.

- Tuno, N., A. Mulahusić, M. Kozličić, Z. Orešković, 2011: Rekonstrukcija granice sutorinskog izlaza Bosne i Hercegovine na Jadransko more s pomoću starih geografskih karata, Kartografija i geoinformacije, 10 (16): 26-55.

- Yang, Y., S. Zhang, J. Yang, L. Chang, K. Bu, X. Xing, 2014: A review of historical reconstruction methods of land use/land cover, Journal of Geographical Sciences, 24: 746-766.

- Zhu, X., 2016: GIS for environmental applications : a practical approach, Routledge, 471 p., London. 


\section{Summary}

Geometric distortions of historical forestry maps represent the main obstacle in process of map integration with other geospatial data. The effects of the practical applications of various methods for removing the map deformations were investigated thoroughly on the tested sheet of the old forestry map of Bosnia and Herzegovina. Software for the automatic computation of the rectangular coordinates of map grid ticks was developed by authors (figure 2). Significant improvement of transformation quality is achieved by the inclusion of all common points from the map coordinate grid (figure 3 ) in the base used in transformation (table 1 and figure 5). Regarding the ability to eliminate the nonuniform and unequally distributed distortions in the map content, the analysis of various geometric transformation methods revealed that the best results of the overall accuracy of map transformation were achieved by use of the complex polynomial and locally sensitive models (figures 6 and 7). Relationship between the Accuracy ${ }_{r}$ values and the polynomial degree used, can be modeled by a polynomial function $y=0.502 x^{2}-5.483 x+22.17$ (figure 8 ). A fifth-order polynomial transformation, based on 81 tie points, results in a $95 \%$ accuracy of $1.5 \mathrm{~mm} \cdot M$.

KEY WORDS: old forestry map, geometric distortions, common points, coordinate transformations 